\title{
Metabolic Control of Phycocyanin Degradation in the Cyanobacterium Synechocystis PCC 6803: a Glucose Effect
}

\author{
By KHALIL ELMORJANI AND MICHAEL HERDMAN* \\ Unité de Physiologie Microbienne, Institut Pasteur, 28 rue du Docteur Roux, 75724 Paris \\ Cedex 15, France
}

(Received 29 January 1987)

\begin{abstract}
Following transfer to medium lacking a nitrogen source, cells of Synechocystis PCC 6803 continued to divide, giving a doubling of cell number after $40 \mathrm{~h}$. Phycocyanin degradation commenced immediately after the transfer, with a rapid phase lasting $5 \mathrm{~h}$ in which $50 \%$ of the phycocyanin disappeared and a slow second phase in which the phycocyanin content decreased to $10 \%$ of its initial value by $24 \mathrm{~h}$. In the presence of glucose, a utilizable carbon source for this facultatively heterotrophic cyanobacterium, phycocyanin was degraded initially at a rate $60 \%$ of that observed in the absence of the sugar and proteolysis was almost completely inhibited after $6 \mathrm{~h}$ when only $27 \%$ of the phycocyanin had been lost; cell division ceased at this time. Photosynthetic $\mathrm{O}_{2}$ evolution decreased rapidly in the presence of glucose and the cells consumed $\mathrm{O}_{2}$ in the light after $7 \mathrm{~h}$, indicative of a switch to oxidative metabolism; net $\mathrm{O}_{2}$ uptake in the absence of glucose occurred only after approximately $25 \mathrm{~h}$. Inhibition of phycocyanin degradation by glucose required metabolism of the sugar, probably via the oxidative pentose phosphate cycle, and appeared to result from irreversible inactivation of the protease.
\end{abstract}

\section{INTRODUCTION}

Boresch (1910) used the term 'nitrogen chlorosis' to describe the rapid depigmentation of cells of Oscillatoria starved of nitrogen, and it was suggested that both chlorophyll and phycocyanin were lost under these conditions (Magnus \& Schindler, 1912; Boresch, 1913; Kingsbury, 1956). However, Allen \& Smith (1969) showed that, although the absorbance of phycocyanin decreased rapidly in the unicellular Anacystis nidulans (synonym Synechococcus PCC 6301, Rippka et al., 1979) during nitrogen starvation, the chlorophyll content remained virtually constant; similar observations on additional strains (four unicellular and five filamentous) supported the conclusion that nitrogen chlorosis results from the preferential loss of phycocyanin and this was confirmed by Neilson et al. (1971) with Anabaena 6411 and Stevens et al. (1981) with Agmenellum quadruplicatum PR-6 (Synechococcus PCC 7002). It was not known whether this loss of absorbance resulted from relatively minor changes in the interaction between the prosthetic group and the apoprotein, rendering the phycocyanin undetectable by spectroscopy, or from complete degradation of the molecule.

Lau et al. (1977) showed by SDS-PAGE that the loss of absorbance of phycocyanin in Synechococcus 6301 resulted from the complete disappearance of both $\alpha$ and $\beta$ subunits of the apoprotein, and the repression of de novo synthesis of these polypeptides. This demonstration of the loss of phycocyanin apoprotein was important: cyanobacteria contain cyanophycin, a copolymer of arginine and aspartate (Simon, 1973), which is also degraded in nitrogen-starved cells (Allen \& Hutchison, 1980); the complete degradation of a light-harvesting pigment in a photosynthetic organism was therefore not necessarily to be expected. Phycobiliproteins constitute up to $50 \%$ of the total protein of the cyanobacterial cell (see Cohen-Bazire \& Bryant,

Abbreviation: MSO, methionine sulphoximine. 
1982) and the amino acids released during degradation presumably permit synthesis of essential proteins and continued cell division.

Foulds \& Carr (1977) showed that Anabaena cylindrica contained an enzyme (phycocyaninase) which degraded partially purified phycocyanin in vitro. Subsequently, Wood \& Haselkorn (1979, 1980 ) identified two proteolytic activities in Anabaena 7120 which appeared in extracts of nitrogen-starved cells, one of which specifically degraded phycobiliproteins in vitro. This activity was also observed in several additional strains of Anabaena (Wood \& Haselkorn, 1980). During starvation of cells of Synechococcus 6301(Yamanaka \& Glazer, 1980) not only phycocyanin but also uncoloured (linker) polypeptides specifically associated with phycobiliprotein were degraded. These results can be interpreted to suggest that the phycocyaninase is either not specific for phycocyanin, or that several enzymes with different specificities are required for the complete breakdown of the phycobilisomes; these possibilities remain to be studied.

Although phycocyaninase appears to be synthesized de novo in response to nitrogen limitation, very little is known of the factors which control its activity. The addition of methionine sulphoximine (MSO), an inhibitor of glutamine synthetase, to cells growing in the presence of combined nitrogen led to the induction of phycocyanin degradation in Anabaena 29143 (Wood \& Haselkorn, 1980) and Spirulina (Boussiba \& Richmond, 1980); since starvation of methionine auxotrophs of Anabaena 29143 (Wood \& Haselkorn, 1980) and Synechococcus 6301 (Yamanaka \& Glazer, 1980) did not induce the degradation of phycocyanin, it was concluded that starvation for any single amino acid other than glutamine did not induce the protease. This conclusion is unlikely, since starvation for leucine had previously been shown to result in phycocyanin degradation in Synechococcus 6301 (Singer \& Doolittle, 1975). The rate of degradation of phycocyanin in whole cells of Anabaena 7118 was light-dependent, being more rapid at high light intensity; degradation did not occur in this autotrophic strain in the light in the absence of $\mathrm{CO}_{2}$, or in the dark (Wood \& Haselkorn, 1980). These results suggested that light itself was not directly involved in controlling phycocyaninase activity but did not distinguish between the possibilities that the intracellular levels of either ATP or a carbon metabolite were important in regulation.

We describe in this communication the degradation of phycocyanin in the unicellular Synechocystis PCC 6803, a facultative heterotroph, and for the first time, the effect of glucose metabolism on the control of this proteolysis.

\section{METHODS}

Organism and growth. Synechocystis PCC 6803, a facultatively heterotrophic unicellular cyanobacterium (Rippka et al., 1979), was obtained from the culture collection of cyanobacteria, Institut Pasteur. Cultures were grown autotrophically at $34^{\circ} \mathrm{C}$ in $40 \mathrm{ml}$ medium BG-11 (Rippka et al., 1979), modified by the addition of $\mathrm{NaHCO}_{3}$ $\left(1 \mathrm{~g} \mathrm{l}^{-1}\right)$, in Erlenmeyer flasks $(250 \mathrm{ml})$ shaken at 100 r.p.m. in a Gallenkamp illuminated orbital incubator gassed with $\mathrm{CO}_{2}\left(61 \mathrm{~h} \mathrm{~h}^{-1}\right)$ at a light intensity of $3000 \mathrm{~lx}$. Mixotrophic growth was achieved under the same conditions but in the presence of glucose $(2 \%, w / v)$. Growth was measured as $O_{580}\left(1 D_{580}\right.$ unit was equivalent to $2.3 \times 10^{7}$ cells $\mathrm{ml}^{-1}$ during exponential growth). Mutant strains were isolated as described in Results. Synechococcus PCC 7002 (previously named Agmenellum quadruplicatum PR-6, see Rippka et al., 1979) was grown at $28^{\circ} \mathrm{C}$, light intensity $2000 \mathrm{~lx}$, with shaking (100 r.p.m.), in medium ASN-III (Rippka et al., 1979) under a gas phase of air $/ \mathrm{CO}_{2}$ $(99: 1, \mathrm{v} / \mathrm{v})$.

Nitrogen starvation. Cells growing exponentially were harvested by centrifugation $(10500 \mathrm{~g}, 15 \mathrm{~min})$, washed once with medium lacking $\mathrm{NaNO}_{3}$, resuspended to approximately $5 \times 10^{7}$ cells ml-1 in the same medium $(40 \mathrm{ml}$ or $200 \mathrm{ml}$ in Erlenmeyer flasks of $250 \mathrm{ml}$ or 11 capacity, respectively) and incubated as above. Glucose $(2 \%, w / v$, unless otherwise stated) or chloramphenicol $\left(10 \mu \mathrm{g} \mathrm{ml}^{-1}\right)$ were added as required.

Estimations. Cell counts were performed on suitably diluted suspensions in a Neubauer counting chamber. Viability was determined by plating appropriate dilutions on agar plates prepared and incubated as described previously (Herdman et al., 1970) except that $\mathrm{NaHCO}_{3}(0.6 \mathrm{M})$ was added as required before pouring to adjust the final pH to 9.3. Oxygen exchange was measured at $34^{\circ} \mathrm{C}$ in a Clark-type $\mathrm{O}_{2}$ electrode under saturating white light. Chlorophyll $a$ was extracted twice from pelleted samples from $8 \mathrm{ml}$ of culture with $90 \%(\mathrm{v} / \mathrm{v})$ methanol $(5 \mathrm{ml}$ for the first extraction, $3 \mathrm{ml}$ for the second, $10 \mathrm{~min}$ each) and its concentration was determined from the $A_{665}$ of the pooled extracts (Marker, 1972). Phycocyanin was measured by a modification (G. Cohen-Bazire, personal communication) of the method of Bennett \& Bogorad (1973). Samples (5-10 ml) of culture were centrifuged, 
resuspended in saline buffer $\left(0.15 \mathrm{M}-\mathrm{NaCl}\right.$ in $\left.0.01 \mathrm{M}-\mathrm{Na}_{2} \mathrm{HPO}_{4}, \mathrm{pH} 7.0\right)$ and disrupted by two passages through a French pressure cell at $110 \mathrm{MPa}$. Following addition of streptomycin sulphate $(1 \%, \mathrm{w} / \mathrm{v})$ the samples were incubated in the dark for $30 \mathrm{~min}$ in ice and then centrifuged $(17000 \mathrm{~g}, 20 \mathrm{~min})$. The phycocyanin content of the supernatant was estimated from the $A_{615}$ and $A_{652}$ (Bennett \& Bogorad, 1973). To facilitate comparison of different experiments, the phycocyanin content of the cultures was expressed as a percentage of that at the initiation of nitrogen starvation, which was approximately $20 \mu \mathrm{g} \mathrm{m} \mathrm{m}^{-1}$. Unless otherwise stated, results of single experiments are shown but are typical of repeated experiments; the errors in determination of phycocyanin were not more than $5 \%$. Protein was measured by the Lowry method with bovine serum albumin as standard.

Uptake and metabolism of $\left[{ }^{14} \mathrm{C}\right]$ glucose. Samples $(5 \mathrm{ml})$ of cultures of Synechocystis PCC $6803(33 \mu \mathrm{g}$ protein $\left.\mathrm{ml}^{-1}\right)$ growing exponentially in the light were transferred to conical flasks $(50 \mathrm{ml})$ containing a centre well, and the flasks were closed with serum stoppers. [U- $\left.{ }^{14} \mathrm{C}\right] \mathrm{Glucose}\left(1 \mu \mathrm{Ci}, 0.05 \mu \mathrm{Ci} \mu \mathrm{mol}^{-1} ; 37 \mathrm{kBq}, 1.85 \mathrm{kBq} \mu \mathrm{mol}^{-1}\right)$ was added and the samples were incubated in the dark $\left(60 \mathrm{~min}, 28^{\circ} \mathrm{C}, 100\right.$ r.p.m. $) . \mathrm{KOH}(1 \mathrm{ml} ; 40 \%$, w/v) was added to the centre well to trap ${ }^{14} \mathrm{CO}_{2}$, which was released from the culture by acidification with trichloroacetic acid $(10 \%$, w/v). Following incubation with shaking for $60 \mathrm{~min}$, the ${ }^{14} \mathrm{CO}_{2}$ content of $0.5 \mathrm{ml}$ of the $\mathrm{KOH}$ was determined by liquid scintillation counting. Cells $(1 \mathrm{ml})$ were filtered (Millipore, $0.45 \mu \mathrm{m}$ pore size), washed three times with $20 \mathrm{ml}$ ice-cold $5 \%(\mathrm{w} / \mathrm{v})$ trichloroacetic acid and the acid-insoluble ${ }^{14} \mathrm{C}$ content was determined by liquid scintillation counting.

\section{RESULTS AND DISCUSSION}

\section{Physiological responses to deprivation of nitrate}

Nitrogen starvation can be achieved by the addition of MSO, an inhibitor of glutamine synthetase, which induced phycocyanin degradation in Anabaena 7118 (Wood \& Haselkorn, 1980) and Spirulina (Boussiba \& Richmond, 1980) in the presence of combined nitrogen. However, at concentrations as high as $1 \mathrm{mM}$ this compound had no effect on the growth of Synechocystis PCC 6803 in the presence of nitrate, and did not induce phycocyanin degradation, suggesting that the cells were impermeable to the inhibitor. Nitrogen starvation was therefore achieved by thorough washing of cells growing exponentially under photoautotrophic conditions and transfer to medium devoid of nitrate. Cell division continued following transfer, although at a decreasing rate (Fig. 1), leading to a doubling of cell number after $40 \mathrm{~h}$. Concomitantly, the total phycocyanin content of the culture decreased rapidly, whereas its

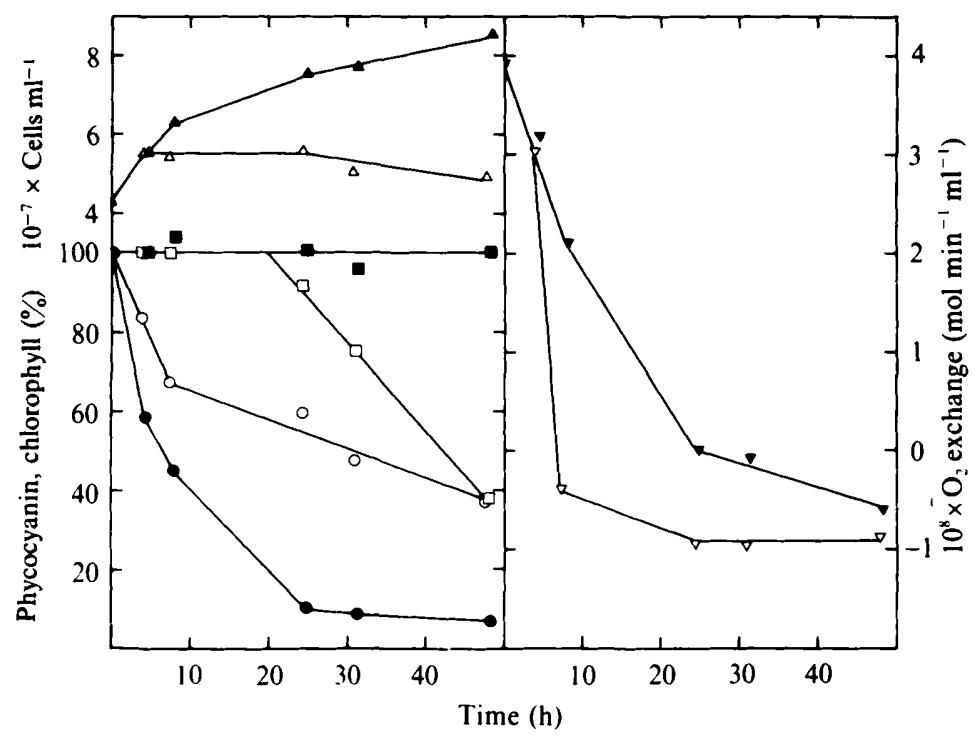

Fig. 1. Response of Synechocystis PCC 6803 to nitrogen deprivation in the presence (open symbols) and absence (filled symbols) of glucose. $\bigcirc, \bigcirc$, Total phycocyanin content of the culture; $\square, \square$, total chlorophyll; $\triangle, \Delta$, cell number; $\nabla, \nabla$, net $\mathrm{O}_{2}$ exchange, where positive and negative values indicate net $\mathrm{O}_{2}$ production and consumption, respectively. Results are from a single experiment. Initial values were: chlorophyll, $2.4 \mu \mathrm{g} \mathrm{ml}^{-1}$; phycocyanin, $19.7 \mu \mathrm{g} \mathrm{ml}^{-1}$. 
chlorophyll content remained constant (Fig. 1) although, as a consequence of cell division, the intracellular content of chlorophyll decreased by $50 \%$, and that of phycocyanin by $97 \%$. The majority ( $>95 \%$ ) of the cells were viable after $48 \mathrm{~h}$. Allen \& Smith (1969) also observed an increase in total cell number of Anacystis nidulans following the onset of phycocyanin degradation. Since cyanobacterial cells growing exponentially contain little cyanophycin (Simon, 1973), and since phycocyanin comprises between $32 \%$ and $41 \%$ of the total protein of cells of Synechocystis PCC 6803 growing exponentially under photoautotrophic conditions (data not shown), this pigment clearly acts as a major source of amino acids for de novo synthesis of other proteins required for continued cell division in the absence of an exogenous nitrogen source.

In contrast, when cells of Synechocystis PCC 6803 were deprived of nitrate in the presence of glucose $(2 \%, w / v)$, cell division ceased after $4 \mathrm{~h}$ (Fig. 1). Phycocyanin degradation occurred at a reduced rate during this period and was subsequently severely retarded (Fig. 1). The chlorophyll content of the culture remained constant for approximately $25 \mathrm{~h}$ and then decreased rapidly (Fig. 1). This loss of chlorophyll correlated neither with the lysis of a proportion (approximately $15 \%$ ) of the cells (detected between 25 and $48 \mathrm{~h}$ ) nor with cell viability, which was reduced to approximately $1 \times 10^{-3}$ at $48 \mathrm{~h}$.

The $\mathrm{O}_{2}$-evolving capacity of cells cultured in the absence of nitrate decreased initially at a rate similar to that of degradation of phycocyanin : photosynthetic $\mathrm{O}_{2}$ evolution was reduced to $50 \%$ at $9 \mathrm{~h}$ at which time $42 \%$ of the phycocyanin remained. The evolution of $\mathrm{O}_{2}$ was undetectable at $25 \mathrm{~h}$ (Fig. 1) and subsequently $\mathrm{O}_{2}$ was consumed in the light, indicating that respiration was occurring. In contrast, $\mathrm{O}_{2}$ production by cells starved of nitrate in the presence of glucose was not detectable after $7 \mathrm{~h}$, and $\mathrm{O}_{2}$ uptake in the light commenced after $7.5 \mathrm{~h}$ (Fig. 1). These results demonstrate a fundamental effect of glucose on the photosynthetic and respiratory capacity of the cells under conditions of nitrogen starvation in the light.

Magnus \& Schindler (1912) predicted that photosynthetic $\mathrm{CO}_{2}$ fixation should decrease in parallel to the loss of pigments and suggested that the function of nitrogen chlorosis was to prevent unbalanced accumulation of fixed carbon under nitrogen starvation. The loss of $\mathrm{O}_{2}$ evolution is consistent with the decrease in ribulose bisphosphate carboxylase activity observed in nitrogen-limited cells of Oscillatoria rubescens (Feuillade et al., 1982) and Anabaena cylindrica (Bradley \& Carr, 1977). The switch to respiratory metabolism is indicative of the operation of the oxidative pentose phosphate cycle under nitrogen starvation in the light. However, these changes do not account for the different rates of phycocyanin degradation in the presence and absence of glucose : after $4 \mathrm{~h}$ of nitrogen starvation, when the rate of phycocyanin degradation in the presence of glucose was approximately $50 \%$ of that in the absence of the sugar, the rates of $\mathrm{O}_{2}$ exchange were virtually identical in the two cultures (Fig. 1).

Phycocyanin degradation in Synechocystis PCC 6803 occurred not only during nitrogen deprivation but also after transfer to medium lacking $\mathrm{SO}_{4}^{2-}$. This proteolysis, which was slower than that observed under nitrogen starvation, was inhibited in the presence of glucose (not shown). The immediate consequence of sulphur starvation would be a decrease in the intracellular pools of cysteine and methionine, implying (in contrast to the findings of Wood \& Haselkorn, 1980, and Yamanaka \& Glazer, 1980) that deprivation of amino acids other than glutamine results in phycocyanin degradation.

\section{Kinetics of phycocyanin degradation in the presence and absence of glucose}

When cells were incubated in the absence of nitrate, phycocyanin degradation commenced immediately and showed two phases. The first occurred at a rapid linear rate during $5 \mathrm{~h}$, by which time only $50 \%$ of the initial quantity remained (Fig. $2 a$ ); thereafter, degradation continued at a reduced rate in the second phase and the phycocyanin content decreased to $10 \%$ after $24 \mathrm{~h}$. In the presence of glucose $(2 \%, \mathrm{w} / \mathrm{v})$, the rate of degradation of phycocyanin in the first phase was initially approximately $60 \%$ of that observed in the absence of this sugar; the rate decreased further after $4 \mathrm{~h}$ and degradation virtually ceased after $6 \mathrm{~h}$ (Fig. $2 a$ ) when only $27 \%$ of the phycocyanin had been lost. Qualitatively similar results were obtained with glucose at concentrations as low as $0.01 \%$ (w/v) (not shown). 


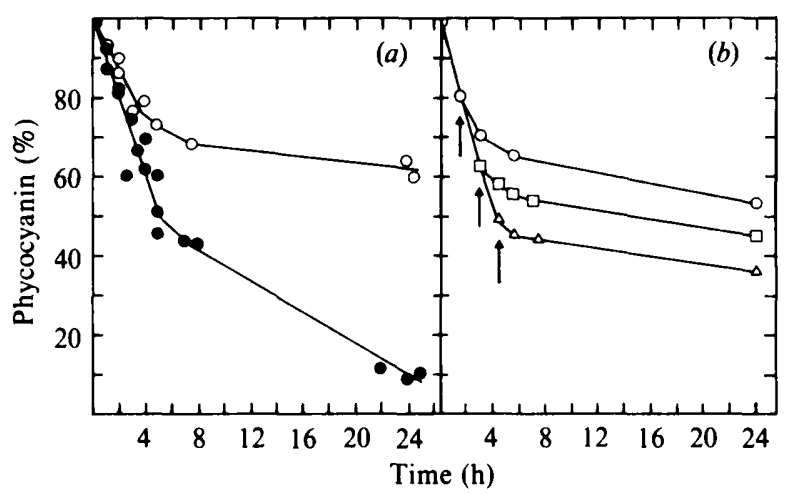

Fig. 2. (a) Degradation of phycocyanin in the presence $(O)$ and absence $(O)$ of glucose in Synechocystis PCC 6803 following transfer to medium lacking nitrate. Data were compiled from two experiments. (b) Inhibition of phycocyanin degradation by glucose added $1.5,3.0$ and $4.5 \mathrm{~h}$ (arrows) after transfer of the cells to medium lacking nitrate. Results are the mean of two experiments.

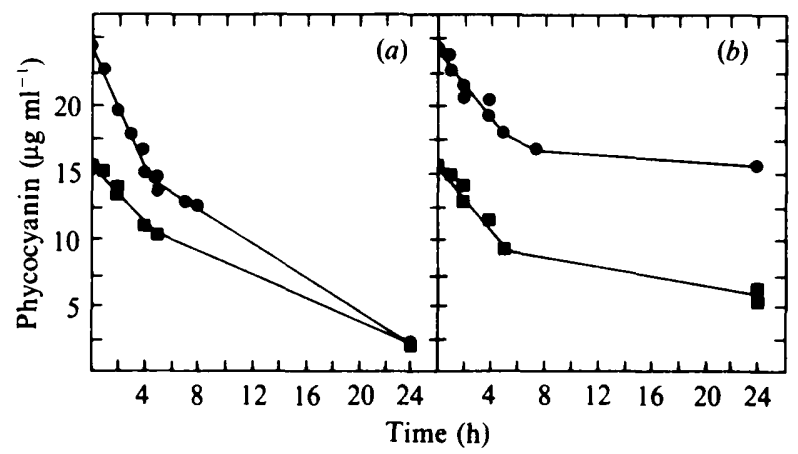

Fig. 3. Degradation of phycocyanin in the absence $(a)$ or presence $(b)$ of glucose by cells previously grown in the presence of nitrate under autotrophic (O) or mixotrophic $(\square)$ conditions. Results are expressed as $\mu \mathrm{g}$ phycocyanin $\mathrm{ml}^{-1}$ because the different cellular contents of phycocyanin under autotrophic and mixotrophic conditions $\left(1.2 \times 10^{-12}\right.$ and $0.8 \times 10^{-12} \mathrm{~g}$ per cell, respectively) do not permit comparison on a percentage basis as in the other figures.

Phycocyanin degradation occurred only when photosystem II was operating, being prevented by 3'-(3,4-dichlorophenyl)-1', $1^{\prime}$-dimethylurea (not shown), a specific inhibitor of this photosystem. Since cells starved of nitrate in the presence of glucose did not show photosynthetic $\mathrm{O}_{2}$ evolution after $7 \mathrm{~h}$ (see above), the continued slow degradation of phycocyanin observed after this time, which proceeded for at least $40 \mathrm{~h}$ (Fig. 1) at a constant rate, was probably the result of non-specific proteolysis.

When glucose was added to cultures of Synechocystis PCC 6803 at various times $(1.5,3.0$ and $4.5 \mathrm{~h}$ ) after transfer to medium lacking nitrate, the rate of degradation of phycocyanin decreased immediately (Fig. $2 b$ ) to that observed in the control (to which glucose was added at the time of transfer to nitrogen-free medium, Fig. $2 a$ ) at the same time, even though more phycocyanin had been degraded than in the control. Inhibition became severe after $4.5 \mathrm{~h}$ and degradation ceased in all cultures after $6 \mathrm{~h}$. The end of the rapid phase of phycocyanin proteolysis, therefore, did not occur when the intracellular content of phycocyanin had decreased to a fixed level, but at a specific time following deprivation of nitrate. This point was independent of the presence of glucose: the sugar, irrespective of the time of addition, exerted an inhibition of phycocyanin degradation which increased progressively during the first phase and was complete after approximately $4 \cdot 5-6 \mathrm{~h}$. 
Table 1. Growth, phycocyanin degradation under nitrogen starvation in the presence of glucose and metabolism of $\left[{ }^{14} \mathrm{C}\right]$ glucose by wild-type and mutant strains (Y10, Y14, Y15, Y27 and Y28) of Synechocystis PCC 6803

Growth was measured in the light and in the dark with glucose $(2 \%, w / v)$ as sole carbon source. Phycocyanin degradation was studied in the light in the absence of nitrate and the incorporation of $\left[{ }^{14} \mathrm{C}\right] \mathrm{glucose}$ was measured in the dark. The results are the means of two determinations differing by not more than $10 \%$.

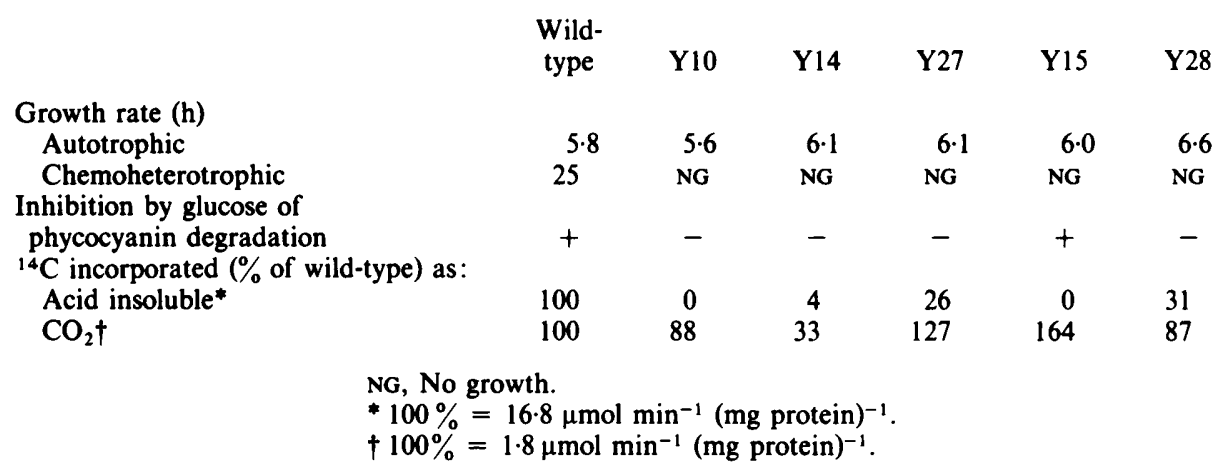

When cells were cultivated overnight mixotrophically (with light and glucose) and then transferred to medium lacking both nitrate and glucose, the effect of glucose persisted for $5 \mathrm{~h}$ (Fig. $3 a$ ): during this period the rate of degradation of phycocyanin was slower than that observed in control cells which had been grown autotrophically in the absence of glucose (Fig. $3 a$ ), and similar to that of the latter cells starved of nitrogen in the presence of glucose (Fig. $3 b$ ). Subsequently, the effect of glucose was lost since degradation continued at a relatively rapid rate (Fig. $3 a$ ) and the phycocyanin content of the cells decreased to the same low level as the control by $24 \mathrm{~h}$. The addition of glucose during starvation of cells previously cultivated under mixotrophic conditions did not increase the degree of inhibition during the first $5 \mathrm{~h}$ (Fig. $3 \mathrm{~b}$ ), the rate of phycocyanin degradation being identical to that observed in the presence of glucose in control cultures previously grown autotrophically. Subsequently, the inhibition in the second phase in the presence of glucose was similar to that of the control. The persistent effect of glucose (Fig. $3 a$ ) was therefore not further enhanced by the continued presence of the sugar.

\section{Requirement for glucose metabolism}

The non-metabolizable glucose analogue 3-O-methylglucose (Beauclerk \& Smith, 1978), which enters the cells of Synechocystis PCC 6803 (Flores \& Schmetterer, 1986), did not inhibit the degradation of phycocyanin when added at a final concentration of $0.1 \%(w / v)$ (not shown), suggesting that a metabolite of glucose, rather than glucose itself, caused the inhibition. Glucose had no effect when added to nitrogen-starved cultures of Synechococcus PCC 7002, a facultative heterotroph (Rippka et al., 1979) capable of growing with glycerol, but not glucose, as carbon source; glycerol $(0.1 \%, \mathrm{w} / \mathrm{v})$ inhibited phycocyanin degradation in this strain (not shown). It is unlikely that glucose and glycerol, molecules very different in structure, inhibit phycocyanin degradation by the same mechanism; it is more probable that a common product of their metabolism is involved.

Further evidence that glucose itself is not the inhibitory compound was obtained from the preliminary study of mutants of Synechocystis PCC 6803 in which phycocyanin degradation is not inhibited, or is inhibited only slightly, in the presence of glucose. These were selected as survivors of nitrate starvation for $48 \mathrm{~h}$ in the presence of glucose. The survivors were plated (100 c.f.u. per plate) on glucose medium containing limiting nitrate $(0 \cdot 1 \%$ of the normal concentration); approximately $50 \%$ of the colonies did not respond to glucose, becoming yellow following deprivation of nitrate after $7 \mathrm{~d}$, in contrast to the wild-type survivors which remained green. These mutants were subcultured and five were selected for further study (Table 1). Unlike the wild-type, none of the mutants were able to grow in the dark at the expense of glucose. They 


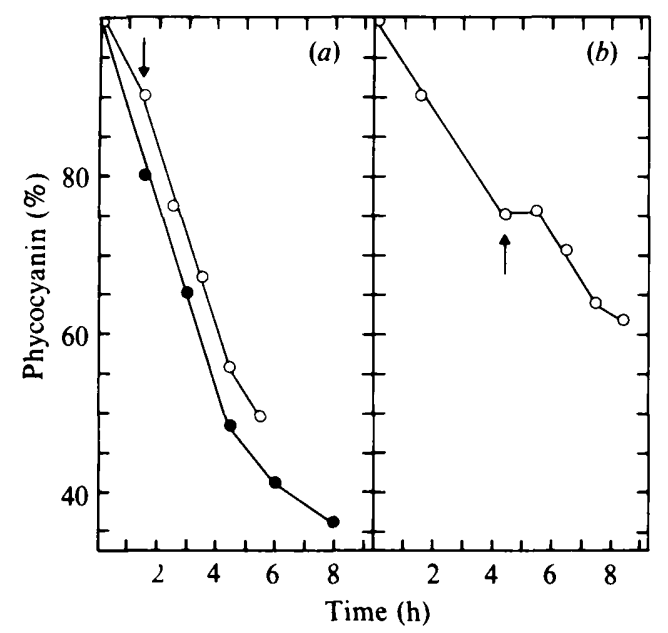

Fig. 4. Degradation of phycocyanin by cells of Synechocystis PCC 6803 initially starved of nitrate in the presence of glucose and transferred to medium lacking glucose after $(a) 1.5 \mathrm{~h}(\mathrm{O})$ or $(b) 4.5 \mathrm{~h}$. Control culture starved of nitrate in the absence of glucose. Arrows indicate the time of transfer.

incorporated little or no ${ }^{14} \mathrm{C}$ from $\left[\mathrm{U}^{-14} \mathrm{C}\right]$ glucose into acid-insoluble material in the dark, but most released $\mathrm{CO}_{2}$ by respiration at rates similar to that of the wild-type (Table 1), implying that glucose was metabolized at least as far as ribulose-5-phosphate, the other product of 6phosphogluconate dehydrogenase. Since glucose entered the cells but phycocyanin degradation during nitrogen starvation in the light was not inhibited in the presence of glucose in four of the mutants (Table 1), glucose itself cannot be the inhibitory compound. As the mutants grew at the same rate as the wild-type under autotrophic conditions (Table 1), but not heterotrophically, they may be deficient in one of the reactions specific to dark metabolism situated after 6phosphogluconate dehydrogenase, in which case the product(s) of one or more of those reactions must be involved in the control of phycocyaninase activity in the wild-type. The other possibility, that the mutants are altered in a controlling region (a regulatory gene or the promoter of the phycocyaninase gene), permitting expression in the presence of glucose, is unlikely, because this would imply that they are double mutants, unable to incorporate carbon from glucose and defective in control of phycocyaninase.

\section{The mechanism of inhibition}

When cells starved of nitrate in the presence of glucose for $1.5 \mathrm{~h}$ were transferred to nitratefree medium lacking glucose, the rate of phycocyanin degradation increased immediately (Fig. $4 a$ ). In contrast, when glucose was removed after $4.5 \mathrm{~h}$ of nitrate deprivation, when the specific proteolysis of phycocyanin had almost ceased, degradation recommenced only after a lag of $60 \mathrm{~min}$ (Fig. $4 \mathrm{~b}$ ); the glucose effect was therefore readily reversible in the early stages of nitrate starvation, but not at the end of the first phase of phycocyanin degradation. After the removal of glucose, the rates of proteolysis in the two cultures were identical to that occurring at the same time in a control culture (Fig. $4 a$ ) starved of nitrate in the absence of glucose, even though less phycocyanin had been degraded in the cultures containing the sugar, and degradation entered the second (slow) phase at the same time as in the control. These results confirm that the end of the rapid phase occurs at a fixed time after deprivation of nitrate and is not related to the quantity of phycocyanin remaining in the cells.

The addition of chloramphenicol following nitrate starvation for $1.5 \mathrm{~h}$ in the absence of glucose resulted in a rapid decrease in the rate of phycocyanin degradation (half-life approximately $1 \mathrm{~h}$ ) but marked inhibition was achieved only after incubation for approximately $2 \mathrm{~h}$ (Fig. 5a). Chloramphenicol, therefore, did not completely inhibit the degradation of phycocyanin. In contrast, the recovery of phycocyaninase activity following removal of glucose 


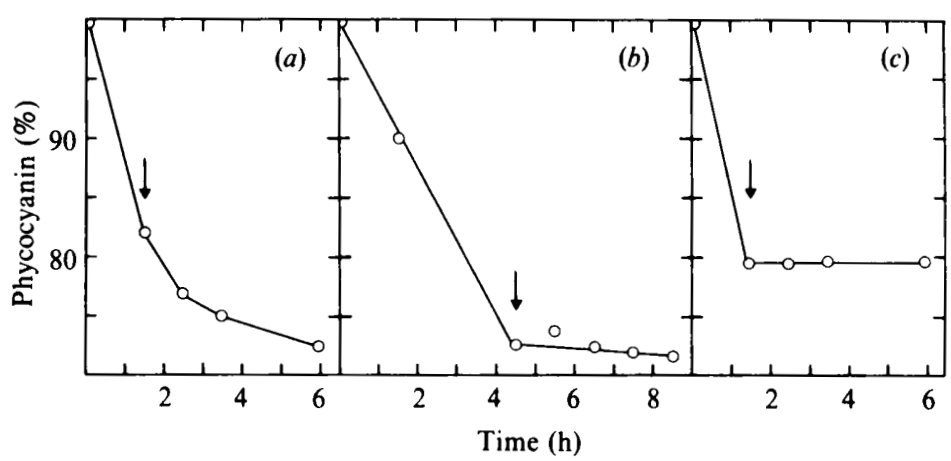

Fig. 5. Inhibition of phycocyanin degradation in Synechocystis PCC 6803 by chloramphenicol (a) and chloramphenicol plus glucose $(c)$ added after $1.5 \mathrm{~h}$ (arrows) of nitrate starvation in the absence of glucose, and (b) by chloramphenicol added at $4.5 \mathrm{~h}$ with simultaneous removal of glucose from cells starved in the presence of the sugar.

after $4.5 \mathrm{~h}$ of nitrate starvation was completely inhibited by the simultaneous addition of chloramphenicol (Fig. 5b), indicating that the enzyme was inactive at this time and that recovery required de novo protein synthesis. Therefore, either the synthesis of phycocyaninase was inhibited and the enzyme was rapidly turned over, or the enzyme had been irreversibly inactivated, by the end of the first phase of degradation in the presence of glucose. Glucose alone (Fig. $2 b$ ) added after $1.5 \mathrm{~h}$ of nitrate starvation had the same effect as chloramphenicol, which could be interpreted as suggesting that the sugar may inhibit synthesis of the enzyme. However, when chloramphenicol and glucose were added simultaneously at $1.5 \mathrm{~h}$, degradation of phycocyanin ceased immediately (Fig. 5c) and therefore the activity of the enzyme was completely inhibited in the presence of glucose during the first phase of degradation when chloramphenicol was added; in the absence of antibiotic, de novo synthesis partly overcame this inhibition.

It is therefore probable that the decrease in the rate of phycocyanin degradation in the presence of glucose results from irreversible inactivation of phycocyaninase, although an additional inhibitory effect on the synthesis of the enzyme cannot be totally excluded. Inhibition of phycocyaninase synthesis in the presence of glucose would be reminiscent of catabolite repression: systems subject to such control include not only those involved in carbon metabolism but also, for example, tryptophanase in Escherichia coli (see Ullmann \& Danchin, 1983; Ullmann, 1985) and proteolytic enzymes involved in sporulation in Bacillus licheniformis (see Bernlohr \& Clark, 1971). Carbon catabolite repression of proteolysis is therefore not without precedent. However, the immediate inhibition of phycocyanin degradation in the presence of glucose resembles catabolite inactivation in, for example, the yeast Saccharomyces cerevisiae, in which one or more metabolites of glucose irreversibly inactivate certain enzymes which then appear to be cleared from the cell by proteolytic action (see Holzer, 1976). The majority of these enzymes are involved in intermediary carbon metabolism and are not essential to the cell when glucose is available; however, one important exception, aminopeptidase I (Frey \& Röhm, 1979), bears a close resemblance to phycocyaninase in being synthesized in response to nitrogen starvation and in degrading specific peptides to permit continued synthesis of other proteins. The function of catabolite inactivation is to lower enzyme activity more rapidly than can occur by catabolite repression alone, where the enzyme content of the cell decreases by dilution resulting from growth.

Although either of these mechanisms is adequate to explain the inhibition by glucose of phycocyanin degradation, this glucose effect is paradoxical. The result of phycocyaninase activity is the utilization of phycobiliproteins to maintain the viability of the cell until favourable growth conditions return; glucose not only inhibits this proteolysis but also causes a marked loss of viability, both processes apparently being a consequence of intermediary metabolism. Since cyanobacteria are able to store large amounts of glucose as glycogen (see 
Smith, 1982) which, like glucose supplied exogenously (see above), can presumably be mobilized via the oxidative pentose phosphate cycle even in the light under nitrogen starvation, a similar control of phycocyanin degradation by endogenous glucose would be predicted. This control would appear to be deleterious to the cell, since survival would not be assured when the intracellular carbon reserves are high. Further studies are required in order to elucidate the physiological basis of these phenomena and also the mechanism(s) of control of phycocyaninase activity.

This work was in part supported by a grant-in-aid to K.E. from the Third World Microbiology Fund of the Society for General Microbiology. Part of the work was performed in the laboratory of Dr F. Joset (CNRS, Gifsur-Yvette, France), whose advice and encouragement we acknowledge. We thank Professor G. Cohen-Bazire for helpful advice and critical comments on the manuscript, and Rosmarie Rippka for valuable discussions.

\section{REFERENCES}

Allen, M. M. \& Hutchison, F. (1980). Nitrogen limitation and recovery in the cyanobacterium Aphanocapsa 6308. Archives of Microbiology 128, 1-7.

Allen, M. M. \& SMITH, A. J. (1969). Nitrogen chlorosis in blue-green algae. Archiv für Mikrobiologie 69, 114-120.

Beauclerk, A. A. D. \& Smith, A. J. (1978). Transport of D-glucose and 3-O-methyl-D-glucose in the cyanobacteria Aphanocapsa 6714 and Nostoc strain MAC. European Journal of Biochemistry 82, 187-197.

BennetT, A. \& Bogorad, L. (1973). Complementary chromatic adaptation in a filamentous blue-green alga. Journal of Cell Biology 58, 419-435.

BERNLOHR, R. W. \& ClARK, V. (1971). Characterization and regulation of protease synthesis and activity in Bacillus licheniformis. Journal of Bacteriology 105, 276-283.

BORESCH, K. (1910). Zur Physiologie der Blaualgenfarbstoffe. Lotos (Prague) 58, 344-345.

BoResCH, K. (1913). Die Farbung von Cyanophyceen und Chlorophyceen in ihrer Abhängigkeit vom Stickstoffgehalt des Substrates. Jahrbucher für wissenshaftliche Botanik 52, 145-185.

Boussiba, S. \& Richmond, A. E. (1980). C-phycocyanin as a storage protein in the blue-green alga Spirulina platensis. Archives of Microbiology 125, 143147.

BRADley, S. \& CARR, N. G. (1977). Heterocyst development in Anabaena cylindrica: the necessity for light as an initial trigger and sequential stages of commitment. Journal of General Microbiology 101, 291-297.

Cohen-Bazire, G. \& Bryant, D. A. (1982). Phycobilisomes: composition and structure. In The Biology of Cyanobacteria, pp. 143-190. Edited by N. G. Carr \& B. A. Whitton. Oxford: Blackwell Scientific Publications.

Feuillade, J., Feuillade, M. \& Jolivet, E. (1982). Photosynthetic metabolism in the cyanophyta Oscillatoria rubescens D.C. Archives of Microbiology 131, 107-111.

FLORES, E. \& SCHMETTERER, G. (1986). Interaction of fructose with the glucose permease of the cyanobacterium Synechocystis sp. strain PCC 6803. Journal of Bacteriology 166, 693-696.

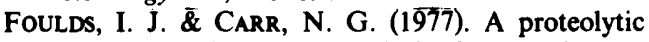 enzyme degrading phycocyanin in the cyanobacterium Anabaena cylindrica. FEMS Microbiology Letters 2, 117-119.
FreY, J. \& RöHM, K.-H. (1979). The glucose-induced inactivation of aminopeptidase $I$ in Saccharomyces cerevisiae. FEBS Letters 100, 261-264.

Herdman, M., Faulkner, B. M. \& Carr, N. G. (1970). Synchronous growth and genome replication in the blue-green alga, Anacystis nidulans. Archiv für Mikrobiologie 73, 238-249.

HolzER, H. (1976). Catabolic inactivation in yeast. Trends in Biochemical Sciences 1, 178-181.

Kingsbury, J. M. (1956). On pigment changes and growth in the blue-green alga, Plectonema nostocorum Bornet ex Gomont. Biological Bulletin 110, 310-319.

Lau, R. H., MacKenzie, M. M. \& Doolittle, W. F. (1977). Phycocyanin synthesis and degradation in the blue-green bacterium Anacystis nidulans. Journal of Bacteriology 132, 771-778.

MAGNuS, W. \& SCHINDleR, B. (1912). Über den Einfluss der Nährsalze auf die Färbung der Oscillarien. Berichte der Deutschen botanischen Gesellschaft 30, 314-320.

MARKER, A. E. H. (1972). The use of acetone and methanol in the estimation of chlorophyll in the presence of phaeophytin. Freshwater Biology 2, 361385.

NeIlson, A., Rippka, R. \& Kunisawa, R. (1971). Heterocyst formation and nitrogenase synthesis in Anabaena sp. A kinetic study. Archiv für Mikrobiologie 76, 139-150.

Rippka, R., Deruelles, J., Waterbury, J. B., Herdman, M. \& Stanier, R. Y. (1979). Generic assignments, strain histories and properties of pure cultures of cyanobacteria. Journal of General Microbiology 111, 1-61.

SIMON, R. D. (1973). Measurement of the cyanophycin granule polypeptide content in the blue-green alga Anabaena cylindrica. Journal of Bacteriology 114, 1213-1216.

Singer, R. A. \& Doolittle, W. F. (1975). Leucine biosynthesis in the blue-green bacterium Anacystis nidulans. Journal of Bacteriology 124, 810-814.

SMITH, A. J. (1982). Modes of cyanobacterial carbon metabolism. In The Biology of Cyanobacteria, pp. 4785. Edited by N. G. Carr \& B. A. Whitton. Oxford: Blackwell Scientific Publications.

Stevens, S. E., Balkwill, D. L. \& Paone, D. A. M. (1981). The effects of nitrogen limitation on the ultrastructure of the cyanobacterium Agmenellum quadruplicatum. Archives of Microbiology 130, 204 212. 
Ullmann, A. (1985). Catabolite repression 1985. Biochimie 67, 29-34.

Ullmann, A. \& Danchin, A. (1983). Role of cyclic AMP in bacteria. Advances in Cyclic Nucleotide Research 15, 1-53.

WOOD, N. B. \& Haselkorn, R. (1979). Proteinase activity during heterocyst differentiation in nitrogen-fixing cyanobacteria. In Limited Proteolysis in Microorganisms, pp. 159-166. Edited by G. N. Cohen \& H. Holzer. Washington, DC: US Government Printing Office.
WOOD, N. B. \& HASElKoRn, R. (1980). Control of phycobiliprotein proteolysis and heterocyst differentiation in Anabaena. Journal of Bacteriology 141, 1375-1385.

Yamanaka, G. \& Glazer, A. N. (1980). Dynamic aspects of phycobilisome structure. Phycobilisome turnover during nitrogen starvation in Synechococcus sp. Archives of Microbiology 124, 39-47. 